\title{
Influence of Physico-Chemical Parameters on Fuel Briquettes Properties Formulated with Mixture of Biomasses
}

\author{
Inna Samomssa ${ }^{1, *}$, Yvette Jiokap Nono², Cornelius Tsamo ${ }^{3,4}$, Mihaela Rodica Dinica5 ${ }^{5}$, Richard Kamga ${ }^{1}$ \\ ${ }^{1}$ Department of Applied Chemistry, National Advanced School of Agro-Industrial Sciences (ENSAI) of the University of Ngaoundere, Ngaoundere, Cameroon. \\ ${ }^{2}$ Department of Chemical Engineering and Environment, University Institute of Technology (IUT) of the University of Ngaoundere, Ngaoundere, Cameroon \\ ${ }^{3}$ Department of Chemistry, Higher Teachers' Training College, University of Maroua, P.O. Box 55 Maroua, Cameroon. \\ ${ }^{4}$ Department of Agricultural and Environmental Engineering, College of Technology, University of Bamenda, P.O.BOX 39, Bambili, Cameroon. \\ ${ }^{5}$ Department of Chemistry, Physics and Environment, Dunărea de Jos" University of Galați, 111 Domneasca Street, 800201 Galați, Romania.
}

\section{A R T I C LED E T A I L S}

\section{Article history:}

Received 27 March 2019

Accepted 18 April 2019

Available online 06 May 2019

Keywords:

Physico-Chemical Parameters

Fractional Factorial Design

Briquette

Biomass

\begin{abstract}
A B S T R A C T
The purpose of this study was to investigate influence of physico-chemical parameters on fuel briquette properties produced from a mixture of cassava and plantain peelings, and corn cob. FTIR and XRD of each biomass was determined and fractional factorial design used in classifying influence of physicochemical parameters on degradation rate and strength of briquette. The results show that the three biomasses have similar infrared spectra. The mains functional groups present are; $\mathrm{OH}$ alcohol, $\mathrm{C}-\mathrm{H}, \mathrm{C}-\mathrm{O}$ and C-C. These could produce hydrogen bond during densification. XRD reveals presence of cellulose and starch in the three biomasses. Cassava peelings have the highest amount of starch compared to others. Thus, cassava peelings can play the rule of binder. Results also reveal that for degradation rate of briquette, the average absolute error (AAE) ranged from $0.00 \%$ to $2.82 \%$ and varies between $0.00 \%$ to $2.88 \%$ for strength. These AAE are closer to zero and can be considered negligible compared to observed responses. This demonstrates the reliability of the models. Besides, adjusted $\mathrm{R}^{2}$, absolute average deviation (AAD), bias factor and exactitude factor obtained are in accordance with interval indicated for validation of model. The influence of evaluated parameters for degradation rate of briquette in descending order of importance are: the briquetting mass, moisture content, briquetting pressure, time before demoulding, diameter of mould, particle size and briquetting temperature. For strength, pressure and particle size are the most influential parameters followed by briquetting time, moisture content, diameter of mould, briquetting mass and briquetting temperature. The influence levels of the different parameters on the strength and degradation rate of briquette simultaneously show that particle size, moisture content, briquetting pressure and briquetting mass are the most important. However, they act in opposite directions for degradation rate and strength of briquette.
\end{abstract}

\section{Introduction}

The attention regarding biomass as an alternative to replace fossil fuels has increased tremendously over the past few years. Thus, the problems related to global warming caused by fossil fuel could be solved [1]. In fact, biomass is a reliable and renewable local energy source in local industries and can reduce reliance on overloaded electricity grids [2]. However, the efficient use of biomass and complete replacement of fossil fuels, in systems originally designed for them, is limited as a result of some undesirable characteristics that biomass presents [3]. Some of these characteristics are high heterogeneity, high moisture content, high alkali content, low heating value, low bulk density, poor grindability, and storage problems [4-7]. Therefore, to improve its properties for industrial applications, biomass often needs to be pretreated [8].

There are many biomass conversion processes to prepare energyefficient biofuels. These methods are physical, agrochemical, thermochemical and biochemical [9]. In physical method of conversion, biomass is densified into solid briquettes while in agrochemical route of conversion; fuel is extracted from freshly cut plants. Thermochemical process of conversion consists of combustion, pyrolysis, gasification and anaerobic digestion to methane. Biochemical route of biomass conversion to fuel consists of ethanol fermentation.

Amongst these methods physical method seems to be a suitable and promising for most developing countries such as Cameroon. In fact, this is a low-cost production process and easy to put in place. Besides, briquetting is environmentally friendly and emit less than half the

*Corresponding Author:samomssa@yahoo.fr(Inna Samomssa) designated emissions stipulated by the Environmental Protection Agencies' 1990 Legislation [10]. When burnt, the products are considered carbon dioxide neutral and result in low levels of ash content. Thus, they are really an eco-alternative to other fossil fuels [10].

In briquetting process, there are three methods to pretreat biomass before densification. These methods are drying, AFEX and carbonization [10]. Although carbonization and AFEX offer advantages to improve thermal properties such as heating value and smoke power, these methods use originally energy which is not always available. In addition, during carbonization, binder properties of biomass are destroyed. Thus, carbonized biomass needs binders which are generally toxics. In contrast, sun energy can be used for drying method. In this way, to avoid utilization of toxics binders, different species of biomass can be mixed to produce fuel briquettes. In Cameroon, cassava peelings, plantain peelings and corn cob are the most produced agricultural waste [11]. Theses biomasses have different properties and could be mixed to produce fuel briquettes.

Previous work on dry briquetting has evaluated influence of moisture content $[12,13]$, pressure $[14,15]$, particle size [16-20] and briquetting temperature [21-25] on thermal and mechanical properties of briquettes. However, these studies have individually studied the influence of these parameters. These studies however, did not evaluate the possible interactions between the different factors. Similarly, the quality of the briquette can be influenced by some physico-chemical parameters namely; briquetting mass, diameter of mould and the time after demoulding. The goal of this study is to investigate influence of physicchemical parameters on fuel briquette properties produced with mixture of cassava peelings, plantain peelings and corn cob. The influence of these biomasses determined physico-chemical parameters on degradation rate and strength of produced briquette was evaluated using a fractional factorial design. 


\section{Experimental Methods}

\subsection{Sampling}

The bio resources used in this work are corn cob, plantain peelings and cassava peelings. Samples collected on the field were washed with tap water followed by distilled water and dried at $50{ }^{\circ} \mathrm{C}$ until constant mass. Powder samples were then prepared by grinding the dried constant mass samples.

\subsection{FTIR Spectroscopy and XRD Characterisation}

FTIR spectra were obtained by means of iS50 RAMAN while X-ray diffractogram was determined using Philips X'Pert PRO diffractometer.

\subsection{Briquette Production and Screening}

Briquettes were produced by the mixture of cassava peelings, plantain peelings and corn cob. Preliminary tests guided the production of briquettes with a mixture of $20 \%, 20 \%$ and $60 \%$ respectively for cassava peelings, plantain peelings and corn cob. Hydraulic mechanic press was used to produce the briquettes.

Screening was done according to the fractional factorial design. This enables the classification of the order of influence of the parameters. The main causes likely to influence the responses were obtained from literature review and the preliminary tests. These parameters are; particle size, moisture content of the raw material, diameter of the mould, mass of mixture, pressing temperature, briquetting pressure, demoulding time and briqueting time. The responses selected are strength and degradation rate of briquette (DRB). The fractional factor test matrix is shown in Table 1 below.

\section{Table 1 Test matrix}

\begin{tabular}{|c|c|c|c|c|c|c|c|c|c|}
\hline \multirow{2}{*}{$\begin{array}{l}\text { S. } \\
\text { No. }\end{array}$} & \multicolumn{7}{|c|}{ Parameters } & \multicolumn{2}{|c|}{ Responses } \\
\hline & $\begin{array}{l}\text { Ps } \\
(\mu \mathrm{m})\end{array}$ & $\begin{array}{l}\text { MC } \\
(\%)\end{array}$ & BM & $\begin{array}{l}\mathrm{t} \\
(\min )\end{array}$ & $\begin{array}{l}\mathrm{P} \\
\text { (Mpa) }\end{array}$ & $\begin{array}{l}\mathrm{D} \\
(\mathrm{cm})\end{array}$ & $\begin{array}{l}\text { BT } \\
\left({ }^{\circ} \mathrm{C}\right)\end{array}$ & DRB & Strength \\
\hline 1 & 300 & 21.0 & 10 & 2.5 & 10.0 & 1.8 & 55 & Y1 & Y1 \\
\hline 2 & 500 & 12.0 & 15 & 0.0 & 15.0 & 1.0 & 30 & Y2 & Y2 \\
\hline 3 & 100 & 12.0 & 15 & 5.0 & 5.0 & 1.0 & 80 & Y3 & Y3 \\
\hline 4 & 100 & 30.0 & 15 & 0.0 & 5.0 & 2.5 & 30 & Y4 & Y4 \\
\hline 5 & 300 & 21.0 & 10 & 2.5 & 10.0 & 1.8 & 55 & Y5 & Y5 \\
\hline 6 & 500 & 30.0 & 5 & 5.0 & 5.0 & 1.0 & 30 & Y6 & Y6 \\
\hline 7 & 100 & 30.0 & 5 & 0.0 & 15.0 & 1.0 & 80 & Y7 & Y7 \\
\hline 8 & 100 & 12.0 & 5 & 5.0 & 15.0 & 2.5 & 30 & Y8 & Y8 \\
\hline 9 & 300 & 21.0 & 10 & 2.5 & 10.0 & 1.8 & 55 & Y9 & Y9 \\
\hline 10 & 500 & 12.0 & 5 & 0.0 & 5.0 & 2.5 & 80 & Y10 & Y10 \\
\hline 11 & 500 & 30.0 & 15 & 5.0 & 15.0 & 2.5 & 80 & Y11 & Y11 \\
\hline
\end{tabular}

Ps:Particle size, MC: Moisture content, $t$ :Time, P:Pressure, D : Diameter of mould, $B T:$ Briquetting temperature; $M:$ Briquetting mass; DRB: Degradation rate of briquette

\subsection{Analysis and Calculation Method}

Degradation rates of briquette (DRB) were determined according to the Shell Household Energy and Health Prograrn method in the WBT (water boiling test) version 3.0 of January 2007 . The briquette was graduated in centimeters and set from above in a Bunsen burner in a hood until the fire is extinguished. The rate of degradation of the material was determined by the ratio of the burned distance as a function of time.

The strength was determined using the Model Brookfield LFRA Texture Analyzer 4500 texturometer. For each experiment, a needle probe was chosen to penetrate the briquettes with a sensitivity of $1 \mathrm{~g}$; a depth of 1.5 $\mathrm{cm}$ and a speed of $0.5 \mathrm{~mm} / \mathrm{s}$. A digital display makes it possible to read the maximum force of travel during the penetration (peak load). This force, expressed in g (force of gravity), is converted to Newton (N) using the conversion factor $1 \mathrm{~g}=0.102 \mathrm{~N}$.

\subsection{Validation of the Model}

Adjusted $\mathrm{R}^{2}$ have to be more than 95\%; Absolute average deviation (AAD) has to be nearer to zero; Exactitude Factor $\left(A_{f 1}\right)$ and bias factor have to be between 0.75 and 1.25; -Probability of Fischer test has to be less than 0.05. These parameters were obtained using Eqs.(1-3).

$$
\begin{aligned}
& \mathrm{R}^{2} \mathrm{adj}=\frac{\sum_{i=1}^{n}\left(y_{i, c}-\overline{y_{e}}\right)}{\sum_{i=1}^{n}\left(y_{i, e}-\overline{y_{e}}\right)} * 100 \\
& \mathrm{AAD}=\left[\sum_{i=1}^{n}\left(\frac{\left|y_{i, e}-y_{i, c}\right|}{y_{i, e}}\right)\right] / n \\
& A_{f_{1}}=10^{\frac{1}{n} \sum_{i=1}^{n} \mid \log \left(\frac{y_{i, e}}{y_{i, e}} \mid\right.}
\end{aligned}
$$

\section{Results and Discussion}

\subsection{Functional Groups and Diffractogram of Materials}

Figs. 1 and 2 below respectively present the functional groups and diffractogram of each biomass.

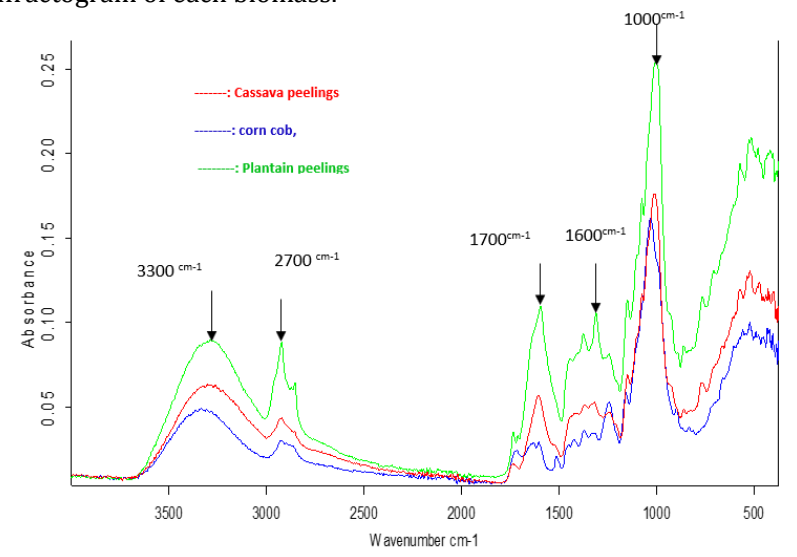

Fig. 1 FTIR of materials

Fig. 1 shows that the three samples have similar infrared spectra. There are four main groups as evident from the absorption bands. These absorption bands are: between $3000-3500 \mathrm{~cm}^{-1}, 2500 \mathrm{~cm}^{-1}, 3000 \mathrm{~cm}^{-1}$, $2000-1400 \mathrm{~cm}^{-1}$ and $1000 \mathrm{~cm}^{-1}$. Absorption band range between $3000-$ $3500 \mathrm{~cm}^{-1}$ is attributed to the elongation vibration of the bonded alcohol group $\mathrm{OH}$ [26], while those between $2500-3000 \mathrm{~cm}^{-1}$ show the presence of C-H [27]. Absorption bands between $2000-1400 \mathrm{~cm}^{-1}$ are characteristic of $\mathrm{C}-\mathrm{O}$ elongation while those at $1000 \mathrm{~cm}^{-1}$ correspond to the $\mathrm{C}-\mathrm{C}$ bond [28].

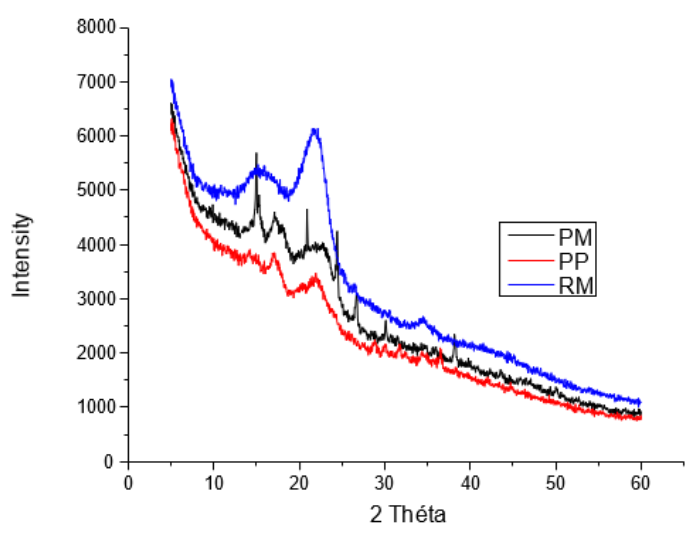

Fig. 2 X-ray diffractogram of materials

This Fig. 2 shows that these biomasses have very different levels of crystallinity. The cassava peelings (PM) has a very high crystallinity with very fine peak at angles $2 \theta$ of $15^{\circ}, 17^{\circ}, 22^{\circ}, 24^{\circ}, 25^{\circ}, 27^{\circ}, 30^{\circ}$ and $38^{\circ}$. The corn cob (RM) has two very wide bands at angles $2 \theta$ of $12^{\circ}$ and $20^{\circ}$. In addition, it has a less intense band at $2 \theta$ of $23^{\circ}$. The bands of plantain peelings are less intense than for the other two compounds and they are found at angles $2 \theta$ of $15^{\circ}$ and $17^{\circ}$. Besides, plantain peelings (PP) spectrum shows a series of fine peaks with very low intensities at angles $2 \theta$ between $24^{\circ}$ and $38^{\circ}$. The literature presents the angles of type I cellulose, type II cellulose and starch for biomass material [29].

Spectrum of cassava peelings reveals the presence of type I cellulose with these peaks at $2 \theta$ equals $15^{\circ}$ and $17^{\circ}$ and the presence of starch with the peaks at $2 \theta$ equals at $22^{\circ}, 25^{\circ}$ and $27^{\circ}$. The peak at $2 \theta$ equal to $22^{\circ}$ generally reflects the type $\mathrm{V}$ crystallinity, which would result from the interactions of granular lipids in the form of monoacylglycerol with the simple helices of amylose, whereas $2 \theta$ equal to $27^{\circ}$ would result from the presence of starch type A [30]. The corn cob shows the presence of type II cellulose with $2 \theta$ angles equal to $12^{\circ}$ and $20^{\circ}$ and the presence of starch with the $2 \theta$ peak equal to $23^{\circ}$. The spectrum of plantain peelings reflects the presence of type II cellulose with angles $2 \theta$ equal to $15^{\circ}$ and $17^{\circ}$ and the presence of starch at $2 \theta$ equal to $24^{\circ}$.

\subsection{Screening}

Table 2 reveals that degradation rate of briquette varies between 0.33 $\mathrm{cm} / \mathrm{min}$ at $0.54 \mathrm{~cm} / \mathrm{min}$ and strength vary between $90.52 \mathrm{~N}$ and $323.38 \mathrm{~N}$. Differences between the both values are $0.23 \mathrm{~cm} / \mathrm{min}$ and $232.8 \mathrm{~N}$ respectively for degradation rate of briquette and strength. These variations are large indicating the influence of the different parameters on 
the properties of fuel briquettes. This table also reveals that for degradation rate of briquette, the average absolute error (AAE) is equal to zero for eight experiments. The three other experiments, AAE are $0.42 \%$, $2.48 \%$ and $2.82 \%$. The same observation was made for strength with the three other experiments with AAE ranging from $1.16 \%$ to $2.88 \%$. These are closer to zero and can be considered negligible compared to observed responses. This demonstrates the reliability of the models.

Table 2 Responses matrix

\begin{tabular}{|c|c|c|c|c|c|c|c|c|c|c|c|}
\hline \multirow{2}{*}{$\begin{array}{l}\text { S. } \\
\text { No. }\end{array}$} & \multicolumn{7}{|c|}{ Parameters } & \multicolumn{2}{|c|}{ Responses } & \multicolumn{2}{|l|}{ AAE } \\
\hline & $\begin{array}{l}\mathrm{Ps} \\
(\mathrm{mm})\end{array}$ & $\begin{array}{l}\text { MC } \\
(\%)\end{array}$ & BM & $\begin{array}{l}\mathrm{t} \\
(\min )\end{array}$ & $\begin{array}{l}\text { P } \\
\text { (Mpa) }\end{array}$ & $\begin{array}{l}\text { D } \\
(\mathrm{cm})\end{array}$ & $\begin{array}{l}\text { BT } \\
\left({ }^{\circ} \mathrm{C}\right)\end{array}$ & DRB & Strength & DRB & Strength \\
\hline$\overline{1}$ & 300 & 21.0 & 10 & 2.5 & 10.0 & 1.8 & 55 & 0.43 & 193.7 & 0.42 & 2.88 \\
\hline 2 & 500 & 12.0 & 15 & 0.0 & 15.0 & 1.0 & 30 & 0.36 & 171.7 & 0.00 & 0.00 \\
\hline 3 & 100 & 12.0 & 15 & 5.0 & 5.0 & 1.0 & 80 & 0.41 & 190.8 & 0.00 & 0.00 \\
\hline 4 & 100 & 30.0 & 15 & 0.0 & 5.0 & 2.5 & 30 & 0.36 & 111.2 & 0.00 & 0.00 \\
\hline 5 & 300 & 21.0 & 10 & 2.5 & 10.0 & 1.8 & 55 & 0.44 & 201.6 & 2.82 & 1.16 \\
\hline 6 & 500 & 30.0 & 5 & 5.0 & 5.0 & 1.0 & 30 & 0.47 & 100.6 & 0.00 & 0.00 \\
\hline 7 & 100 & 30.0 & 5 & 0.0 & 15.0 & 1.0 & 80 & 0.43 & 199.4 & 0.00 & 0.00 \\
\hline 8 & 100 & 12.0 & 5 & 5.0 & 15.0 & 2.5 & 30 & 0.54 & 223.4 & 0.00 & 0.00 \\
\hline 9 & 300 & 21.0 & 10 & 2.5 & 10.0 & 1.8 & 55 & 0.42 & 202.5 & 2.48 & 1.63 \\
\hline 10 & 500 & 12.0 & 5 & 0.0 & 5.0 & 2.5 & 80 & 0.53 & 90.52 & 0.00 & 0.00 \\
\hline 11 & 500 & 30.0 & 15 & 5.0 & 15.0 & 2.5 & 80 & 0.33 & 159.1 & 0.00 & 0.00 \\
\hline
\end{tabular}

AAE: Average absolute error

\subsection{Validation of Model}

Table 3 illustrates that absolute average deviation (AAD) is closer to zero for strength and degradation rate. This is in agreement with the interval set to validate average deviation absolute analysis [31]. Besides it, the bias factor and exactitude factor values for both responses are equal to 1. The validation condition of the both factors is that their values should be between 0.75 and 1.25 [31]. In addition, adjusted $\mathrm{R}^{2}$ of the both is closer to $100 \%$. On these bases, models from strength and degradation rate of briquette are validated.

Table 3 Condition to validate models

\begin{tabular}{lllll}
\hline Responses & $\mathrm{R}^{2}$ Adjusted (\%) & $\mathrm{AAD}$ & Biais factor & Exactitude Factor \\
\hline Strength & 99.17 & 0.01 & 1.00 & 1.00 \\
DRB & 97.04 & 0.01 & 1.00 & 1.00 \\
\hline AAD: Absolute Average Deviation & & &
\end{tabular}

Table 4 shows the P-value of each factor for degradation rate of briquette and strength. Statistical analyses reveal that the p-value less than 0.05 indicate parameters are significantly different from zero at the $95 \%$ confidence level. This table also reveals that for degradation rate of briquette, moisture content and briquetting mass have P-value less than 0.05 . In view of these probability values, it can be said that moisture content and the briquetting mass significantly influence degradation rate of briquette. On the other hand, p-value of strength shows that particle size, moisture content, briquetting time, briquetting pressure and diameter of mould have a significant effect on the response. Their respective P-value is $0.004 ; 0.014 ; 0.014 ; 0.002$ and 0.020 . The $\mathrm{R}^{2}$ statistic indicates that the adjusted model accounts for $99.41 \%$ of the degradation rate variability. The adjusted $\mathrm{R}^{2}$ statistic, which is preferable for comparing models with different numbers of explanatory variables, is 97.04\%. For strength, the $\mathrm{R}^{2}$ statistic indicates that the adjusted model explains $99.17 \%$ while the $\mathrm{R}^{2}$ is $99.83 \%$. Thus obtained, difference between $\mathrm{R}^{2}$ and adjusted $\mathrm{R}^{2}$ is negligible.

Table 4 P-Value of each parameters

\begin{tabular}{lll}
\hline Parameters & DRB & Strength \\
\hline Particle size $(\mu \mathrm{m})$ & 0.295 & 0.004 \\
Moisture content $(\%)$ & 0.018 & 0.014 \\
Briquetting mass $(\mathrm{g})$ & 0.004 & 0.096 \\
Time (min) & 0.134 & 0.014 \\
Pressure $(\mathrm{Mpa})$ & 0.063 & 0.002 \\
Diameter of mould $(\mathrm{cm}$ & 0.127 & 0.020 \\
Briquetting temperature $\left({ }^{\circ} \mathrm{c}\right)$ & 0.663 & 0.099 \\
\hline
\end{tabular}

\subsection{Modeling}

The equations below present model of each response. These equations show that, $X_{1}, X_{2}, X_{3}, X_{5}$ and $X_{7}$ negatively influence degradation rate of briquette, while $\mathrm{X}_{4}$ and $\mathrm{X}_{6}$ influence positively. $\mathrm{X}_{1}, \mathrm{X}_{2}, \mathrm{X}_{3}, \mathrm{X}_{4}, \mathrm{X}_{5}, \mathrm{X}_{6}$ and $\mathrm{X}_{7}$ are particle size, moisture content, briquetting mass, time after briquetting, pressure, diameter and briquetting temperature, respectively. For strength, $\mathrm{X}_{1}, \mathrm{X}_{2}, \mathrm{X}_{6}$ and $\mathrm{X}_{7}$ negatively influence the model while $\mathrm{X}_{3}, \mathrm{X}_{4}$ and $X_{5}$ influence positively.

Degradation rate of briquette $=0.8236-0.000022 \mathrm{X}_{1}-0.003560 \mathrm{X}_{2}-$ $0.009829 \mathrm{X}_{3}+0.00304 \mathrm{X}_{4}-0.002358 \mathrm{X}_{5}+0.01050 \mathrm{X}_{6}-0.000063 \mathrm{X}_{7}(4)$

Strength $=12.326-0.005103 \mathrm{X}_{1}-0.07821 \mathrm{X}_{2}+0.0365 \mathrm{X}_{3}$

$+0.2058 \mathrm{X}_{4}+0.2720 \mathrm{X}_{5}-0.5752 \mathrm{X}_{6}-0.00718 \mathrm{X}_{7}$

\subsection{Pareto Diagrams}

The influence of evaluated parameters for degradation rate of briquette in descending order of importance are: the briquetting mass, moisture content, briquetting pressure, time before demoulding, diameter of mould particle size and briquetting temperature (Fig. 3). The influence of the briquetting mass is twice as fast as that of moisture content and about four times that of pressure. These three factors have negative contributions on degradation rate of briquette. The negative value of the contribution of the briquetting mass is due to the fact that the greater the quantity of the material, the longer the combustion time will be. It can be considered that when the briquette contains water the combustion is done in two phases; the evaporation of water in the first phase and combustion in the second phase. This double step slows the degradation of briquette. The higher the pressure, the more compact the briquette is. Under these conditions the diffusion of the air is weak and consequently the combustion is low. A large diameter of briquette and thus a larger surface area gives a greater contact between the materials and the oxygen therefore the degradation is faster.

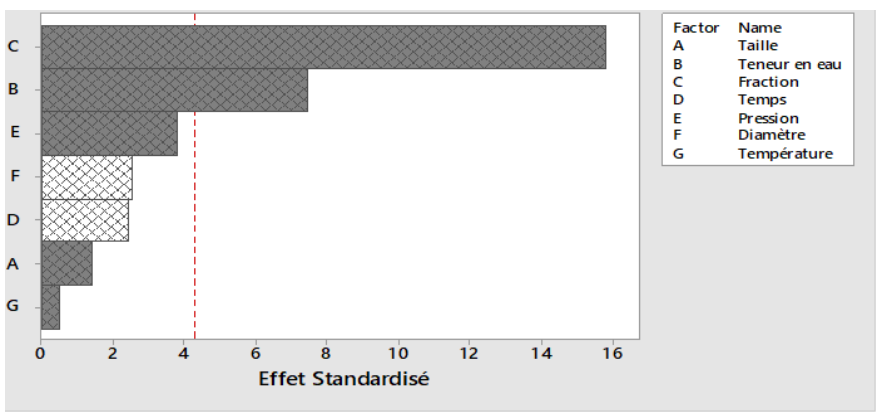

Fig. 3 Pareto diagram of degradation rate of briquette

For strength, pressure and particle size are the most influential factors followed by briquetting time, moisture content and diameter of mould (Fig. 4). Mass and temperature come last. Pressure, time, fraction and temperature have a positive contribution to the force. On the other hand, particle size, moisture content and diameter of mould have a negative contribution. The positive contribution of the pressure is that the higher the pressure, the denser and compact the briquette is. Higher times before demoulding correspond to an additional period of hardening for the briquette. The negative influence of particle size results from the fact that the larger the size of the particles, the smaller the contact area between them and the lower the density of the briquette obtained. Water acts in the briquette as a dispersant of solid materials, hence its negative contribution to the hardness of the briquette.

The influence of these parameters taken simultaneous on strength and degradation rate of briquettes, shows that particle size, moisture content, briquetting pressure and briquetting mass are the most important However, they act in opposite directions for degradation rate of briquette and for strength.

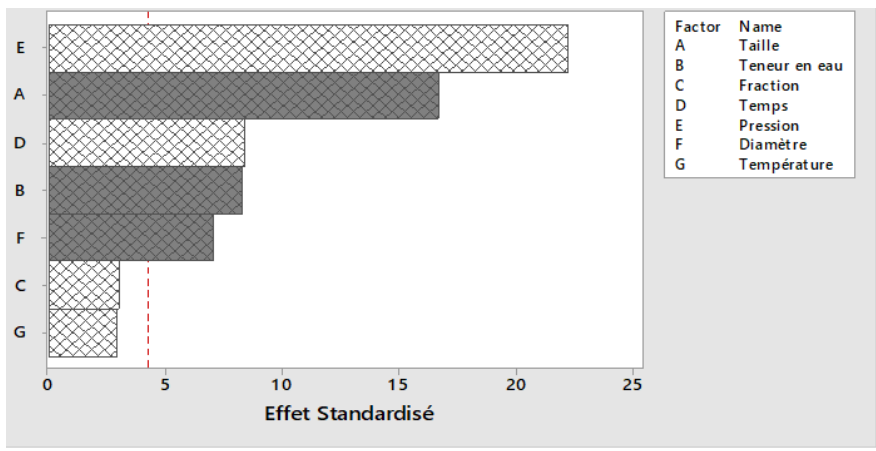

Fig. 4 Pareto Diagram of strength

\section{Conclusion}

The aim of this study was to classify the influence of physico-chemical parameters on fuel briquettes properties. The results show that functional group present on the three biomasses could make hydrogen bond during densification. In addition, diffractogram reveals the presence of starch in the three biomasses and can be gelatinized during densification to improve contact between particles. Results also reveal that for degradation rate of briquette, the average absolute error (AAE) is ranged from $0.00 \%$ to $2.82 \%$ and varies between $0.00 \%$ to $2.88 \%$ for strength. These AAE are closer to zero and can be considered negligible compared 
to observed responses. This demonstrates the reliability of the models. Besides, adjusted $\mathrm{R}^{2}$, absolute average deviation, bias factor and exactitude factor obtained value are in accordance with interval indicated for validation. The influence levels of the different parameters on the strength and degradation rate of briquette simultaneous show that particle size, moisture content, briquetting pressure and briquetting mass are the most important. However, they act in opposite directions for degradation rate of briquette and for strength.

\section{Acknowledgement}

The authors thank the Agence Universitaire de la Francophonie (AUF) for the financial support under the grant "Soutien aux Equipes de Recherche" (BACGL-2014-53) and also thank Department of Chemistry, Physics and Environment of Dunărea de Jos" University of Galați for equipment.

\section{References}

[1] A. Molino, F. Nanna, A. Villone, Characterization of biomasses in the southern Italy regions for their use in thermal processes, Appl. Energy 131 (2014) 180188.

[2] S.C. Canzana, Biomass energy conversion, sustainable growth and applications in renewable energy sources, InTech, Texas A\&M University, USA, 2011, pp.210-226.

[3] J.S. Tumuluru, R.J. Hess, R.D. Boardman, C.T. Wright, T.L Westover, Formulation, pretreatment, and densification options to improve biomass specifications for co-firing high percentages with coal, Ind. Biotechnol. 8 (2012) 113-132.

[4] Q.V. Bach, O. Skreiberg, Upgrading biomass fuels via wet torrefaction: A review and comparison with dry torrefaction, Renew. Sustain. Energy Rev. 54 (2016) 665-677.

[5] B. Acharya, A. Dutta, J. Minaret, Review on comparative study of dry and wet torrefaction, Sustain. Energy Technol. 12 (2015) 26-37.

[6] J.M. Castellano, M. Gomez, M. Fernandez, L.S. Esteban, J.E. Carrasco, Study on the effect of raw materials composition and pelletization condition on the quality and properties of pellets obtained from different woody and non woody biomasses, Fuel 139 (2015) 629-636.

[7] D.R. Nhuchhen, P. Basu, B. Acharya, A comprehensive review on biomass torrefaction, Int. J. Renew. Energy Biofuels. 2014 (2014) 1-56.

[8] M. Puig-Arnavat, J. Ahrenfeldt, B.U. Henriksen, Validation of a multiparameter model to investigate torrefied biomass pelletization behavior, energy and fuel, Energy Fuels 31 (2017)1644-1649.

[9] S. Alok, K.S. Rawat, O.P. Nautiyal, V.T. Chavdal, Biomass to fuel: conversion techniques, Energy resources: Development, harvesting and management, Uttarakhand Education and Research Centre (USERC), India, 2016

[10] C. Antwi-Boasiako, B.B. Acheampong, Strength properties and calorific values of sawdust-briquettes as wood-residue energy generation source from tropical hardwoods of different densities, Biomass Bioener. 85 (2016) 144-152.

[11] I. Samomssa, Y.N. Jiokap, R. Kamga, Energy potential of waste derived from some food crop products in the northern part of Cameroon, Int. J. Energy Power Eng. 4 (2015) 342-352.
[12] T.U. Onuegbu, U.E. Ekpunobi, I.M. Ogbu, M.O. Ekeoma, F.O. Obumselu., Comparative studies of ignition time and water boiling test of coal and biomass briquettes blend, Int. J. Res. Rev. Appl. Sci. 7 (2011) 153-159.

[13] J. Asian, The best biobriquette energy dimension and its particle size, Energy Environ. 9 (2008) 161-175

[14] C.K.W. Ndiema, P.N. Manga, C.R. Ruttoh, Influence of die pressure on relaxation characteristics of briquetted biomass, Energy Conver. Manag. 43 (2002) $2157-$ 2161.

[15] S. Yaman, M. Ahan, H. Haykiriaçma, S. Küçükbayrak, Production of fuel briquettes from olive refuse and paper mill waste, Fuel Proces. Technol. 68 (2000) 23-31.

[16] A. Menind, P. Križan, L. Šooš, M. Matúš, Kers Tallinn Estonia, Optimal Conditions for Valuation of wood waste by briquetting, International DAAAM Baltic Conference Industrial Engineering, Estonia, 2012.

[17] P. Križan, M. Matúš, L. Šooš, J. Kers, P. Peetsalu, Ü. Kask, A. Menind, Briquetting of municipal wastes by different technologies for quality and properties evaluation, Agronomy Res. 19 (2011) 115-123.

[18] M. Rizki, Y. Tamai, K. Koda, Y. Kojima, M. Terazawa, Wood density variations of tropical wood species: Implications to the physical properties of sawdust as substrate for mushroom cultivation in wood, Res. J. Indon. Wood Res. Soc. 1 (2010) 34-39.

[19] J. Kers, P. Kulu, A. Aruniit, V. Laurmaa, P. Križan, L. Šooš, Ü. Kask, Determination of physical, mechanical and burning characteristics of polymeric waste material briquettes, Proc. Estonian Acad. Sci. Eng. 16 (2010) 307-316.

[20] N.P.K. Nielsen, D.J. Gardnerb, Effect of extractives and storage on the pelletizing process of sawdust, Fuel 89 (2010) $94-98$.

[21] N. Manickam, Effect of moisture content and particle size on bulk density, porosity, particle density and coefficient of friction of coir pith, J. Eng. Sci. Technol. 3(4) (2011) 652-661.

[22] C.M. Elinge, A.U. Itodo, Yusuf, H. Birnin, U.A. Yauri, A.N. Mbongo, Blending coal char on the combustion profiles of fuel briquettes, Pelagia Res. Lib. 2 (2011) 152-157.

[23] J.T. Oladeji, Fuel characterization of briquettes produced from corncob and rice husk resides, Pacific J. Sci. Technol. 11 (2010) 101-106.

[24] Z. Colley, O.O. Fasina, D. Bransby, Y.Y. Lee, Moisture effect on the physical characteristics of switchgrass pellets, Am. Soc. Agri. Biol. Eng. 49 (2006) 18451851.

[25] S. Mani, L.G. Tabil, S. Sokhansanj, Specific energy requirement for compacting corn stover, Bioresource Technol. 97 (2006) 1420-1426.

[26] A. Saeed, M. Sharif, M. Iqbal, Application potential of grapefruit peel as dye sorbent: Kinetics, equilibrium and mechanism of crystal violet adsorption. J. Hazard. Mater. 179 (2010) 564-572.

[27] M.T. Uddin, M. Rukanuzzaman, M.M.R. khan, M.A. Islam, Adsorption of methylene blue from aqueous solution by jackfruit (Artocarpus heteropyllus) leaf powder: A fixed-bed column study, J. Environ. Manag. 90 (2009) 34433450

[28] O. Gulnaz, A. Kaya, S. Dincer, The reuse of dried activated sludge for adsorption of reactive dye, J. Hazard. Mater. 134 (2006) 190-196.

[29] W.P. Flauzino Neto, H.A. Silverio, N.O. Dantas, D. Pasquini, Extraction and characterization of cellulose nano crystals from agro-industrial residue and hulls, Indust. Crops Product 42 (2013) 480-488.

[30] R.M. Nguimbou, Nutritional potential and physicochemical properties of tuber powders of Cyrtosperma merkusii (H. Schott), unconventional two-color taro, Doctorate thesis, University of Ngaoundere, Cameroon, 2010.

[31] Goupy Jacques, Experimental Designs, Revue Modulad. 34 (2006) 74-116. 